REPORTS OF MORPHOLOGY
$\begin{gathered}\text { Official Journal of the Scientific Society of Anatomists, } \\ \text { Histologists, Embryologists and Topographic Anatomists } \\ \text { of Ukraine } \\ \text { journal homepage: https://morphology-journal.com }\end{gathered}$

\title{
Positive trend of Ukrainian surgeons' attitude to simultaneous operations: analysis of survey results
}

Parkhomenko K.Yu., ${ }^{1}$ Boiko V.V., ${ }^{2}$ Kalinkina N.V., ${ }^{3}$ Drozdova A.G. ${ }^{2}$

${ }^{1}$ Kharkiv National Medical University, Kharkiv, Ukraine

${ }^{2}$ State Institution "Institute of General and Emergency Surgery named after V.T. Zaitsev of the National Academy of Medical Sciences of Ukraine", Kharkiv, Ukraine

${ }^{3}$ Kharkiv Regional Institute of Public Administration of the National Academy of Public Administration, Kharkiv, Ukraine

\section{ARTICLE INFO}

Received: 4 August, 2020

Accepted: 9 Septembery, 2020

UDC: $616-089(477)]: 303.621 .3$

\section{CORRESPONDING AUTHOR}

e-mail: pku70@ukr.net Parkhomenko K.Yu.
In recent years, there has been an increase in attention to simultaneous operations, but their frequency does not meet real needs. The aim of the study was to determine the dynamics of surgeons' awareness of simultaneous surgery in combined abdominal pathology. The results of the survey of surgeons of surgical inpatient departments of regional, district and city hospitals, as well as institutes and university clinics of Poltava, Sumy, Rivne, Kharkiv, Luhansk and Donetsk regions (except for territories not controlled by the Ukrainian authorities) were analyzed. The sample was random within a homogeneous general population of surgeons. The first survey, which included 724 doctors, was conducted in 2016. The re-survey, conducted in 2020, involved 153 doctors. The subject of the survey was the state of simultaneous surgical interventions in surgical departments departments and the personal attitude of specialists to this type of intervention. The comparison of the survey results in 2016 and in 2020 was carried out using the criterion $x^{2}$. In response to questions about the feasibility of simultaneous implementation, there is an increase in the proportion of doctors who consider these losses appropriate - from $86.3 \%$ to $96.7 \%$. The following questions show that practicing surgeons are more likely to perform simultaneous interventions themselves - their share has increased from $66.3 \%$ to $86.3 \%$. At the same time, the number of doctors with skills and knowledge of a related specialty increased by $20 \%$ (from $27 \%$ to $47.1 \%$ ), however, it is still less than half of doctors. The share of physicians who consider it appropriate to master a related specialty to be able to perform a wider range of simultaneous interventions increased from $68.0 \%$ to $80.4 \%$. The share of physicians with minimally invasive techniques to perform simultaneous operations increased from $26.0 \%$ to $55.6 \%$. There is a positive trend in the attitude of practitioners to simultaneous operations. For the further development of simultaneous operations in combined pathology, it is necessary to train "endoscopic surgeons", who must have the skills of related specialties.

Key words: simultaneous operations, abdominal pathology, interrogation, dynamics of subjective attitude.

\section{Introduction}

Simultaneous operations (SO) for combined diseases requiring surgical treatment are performed in many surgical, gynecological, urological and other departments, but have not yet become routine. Moreover, the number of such operations is much smaller than the prevalence of combined pathology $-1.5-6 \%$ vs. $10-20 \%$ [20]. In the publications devoted to this problem, among the advantages of simultaneous operations are mentioned the $\mathrm{SO}$ of two or more diseases, each of which has a risk of complications; eliminates the danger of the operation in the conditions of the adhesion process during the second operation; high economic efficiency; getting rid of repeated preoperative stress in anticipation of the second operation. It is reported that there is no difference between their direct results with the results of isolated operations, but with a decrease in the number of complications after simultaneous operations is less compared to their total number after staged interventions $[8,14,15,20]$. The most 
common arguments against simultaneous operations are an increase in the volume and duration of surgery, which increases the degree of surgical aggression and the risk of complications $[10,12,20]$, but these shortcomings are offset by the introduction of new surgical techniques [1].

Therefore, often a small number of simultaneous interventions can be explained by purely subjective factors - the attitude of practicing surgeons and, possibly, incomplete examination of patients before surgery.

The aim of the study was to determine the dynamics of surgeons' awareness of simultaneous operations in combined abdominal pathology.

\section{Materials and methods}

Connection of work with scientific programs, plans and topics: The work was performed within the planned research work of Kharkiv National Medical University "Development of surgical technologies for diagnosis and treatment of diseases and injuries of the digestive system using hybrid (open and minimally invasive) operations" (state registration № 0119U002909).

The results of a survey of surgeons of surgical inpatient departments of regional, district and city hospitals, as well as institutes and university clinics of Poltava, Sumy, Rivne, Kharkiv, Luhansk and Donetsk regions (except for areas not controlled by the Ukrainian authorities) were analyzed. The sample was random within a homogeneous general population of surgeons. Respondents participated in the survey on a voluntary basis. The first survey, which included 724 doctors, was conducted in 2016. The re-survey, conducted in 2020, involved 153 doctors.

The questions of the questionnaire were developed independently. The subject of the survey was the state of conducting SO in these departments and the personal attitude of specialists to this type of intervention.

Processing of survey results was carried out using a program for processing sociological questionnaires [17]. The comparison of the results of the survey conducted in 2016 and in 2020 was carried out using the criterion $x^{2}$ [16].

\section{Results}

The questions included in the questionnaire and the answers of the respondents are given in Table 1.

A comparative analysis of the structure of answers to the main questions revealed the following. In the answers

Table 1. Survey results of surgeons in 2016 and 2020.

\begin{tabular}{|c|c|c|c|}
\hline Questions and answers & $\begin{array}{l}2016 \\
(n=724)\end{array}$ & $\begin{array}{c}2020 \\
(n=153)\end{array}$ & $p$ \\
\hline $\begin{array}{l}\text { Do you consider it appropriate to implement SO? } \\
\text { - yes } \\
\text { - no }\end{array}$ & $\begin{array}{c}625(86.3 \%) \\
99(13.7 \%)\end{array}$ & $\begin{array}{c}148(96.7 \%) \\
5(3.3 \%)\end{array}$ & $<0.001$ \\
\hline $\begin{array}{l}\text { Actually, do you perform SO? } \\
\text { - yes } \\
\text { - no }\end{array}$ & $\begin{array}{c}480(66.3 \%) \\
244(33.7 \%)\end{array}$ & $\begin{array}{l}132(86.3 \%) \\
21(15.7 \%)\end{array}$ & $<0.001$ \\
\hline $\begin{array}{l}\text { Do you now have the relevant skills and knowledge of a related specialty (documented) which help } \\
\text { you perform SO on your own? } \\
\text { - yes } \\
\text { - no }\end{array}$ & $\begin{array}{l}195(27.0 \%) \\
529(73.0 \%)\end{array}$ & $\begin{array}{l}72(47.1 \%) \\
81(52.9 \%)\end{array}$ & $<0.001$ \\
\hline $\begin{array}{l}\text { Do you consider it appropriate to master a related specialty to be able to perform SO on your } \\
\text { own? } \\
\text { - yes } \\
\text { - no }\end{array}$ & $\begin{array}{l}492(68.0 \%) \\
232(32.0 \%)\end{array}$ & $\begin{array}{l}123(80.4 \%) \\
20(19.6 \%)\end{array}$ & $<0.001$ \\
\hline $\begin{array}{l}\text { Do you currently (at the time of the survey) have techniques for performing SO in a minimally } \\
\text { invasive way? } \\
\text { - yes } \\
\text { - no }\end{array}$ & $\begin{array}{l}188(26.0 \%) \\
536(74.0 \%)\end{array}$ & $\begin{array}{l}85(55.6 \%) \\
68(44.4 \%)\end{array}$ & $<0,001$ \\
\hline $\begin{array}{l}\text { Have you ever actually worked as a "guest consultant" to help colleagues in another specialty in } \\
\text { their SO performing? } \\
\text { - yes } \\
\text { - no }\end{array}$ & $\begin{array}{c}637(88.0 \%) \\
87(12.0 \%)\end{array}$ & $\begin{array}{l}112(73.2 \%) \\
41(26.8 \%)\end{array}$ & $<0.001$ \\
\hline $\begin{array}{l}\text { What is the most significant advantage of SO you can highlight? } \\
\text { - getting rid of several diseases } \\
\text { - economic benefits } \\
\text { - avoiding the risk of repeated interventions }\end{array}$ & $\begin{array}{c}32(4.4 \%) \\
148(20.4 \%) \\
544(75.1 \%)\end{array}$ & $\begin{array}{c}3(1.9 \%) \\
31(20.3 \%) \\
119(77.8 \%)\end{array}$ & $>0,05$ \\
\hline $\begin{array}{l}\text { What, in your opinion, can be attributed to the most significant disadvantage of SO? } \\
\text { - change the location of the operating team during the intervention } \\
\text { - increased risk of complications } \\
\text { - increased duration of intervention }\end{array}$ & $\begin{array}{c}44(6.0 \%) \\
175(24.2 \%) \\
505(69.8 \%)\end{array}$ & $\begin{array}{c}14(9.2 \%) \\
28(18.3 \%) \\
111(72.5 \%)\end{array}$ & $>0,05$ \\
\hline
\end{tabular}

Notes: $\mathrm{p}$ - the reliability of the difference between 2016 and 2020 by criterion $\mathrm{X}^{2}$. 
to the first question regarding the opinion of doctors about the expediency of SO, there is an increase in the proportion of doctors who consider these interventions appropriate from $86.3 \%$ to $96.7 \%$. The following questions showed that practicing surgeons more often perform SO themselves - their share increased from $66.3 \%$ to $86.3 \%$. At the same time, the number of doctors with skills and knowledge of a related specialty increased by $20 \%$ (from $27 \%$ to $47.1 \%$ ), however, it is still less than half of doctors. The share of physicians who consider it appropriate to master a related specialty to be able to perform a wider range of SO has increased from $68.0 \%$ to $80.4 \%$.

Interestingly, the proportion of physicians with minimally invasive techniques for performing $\mathrm{SO}$ increased from $26.0 \%$ to $55.6 \%$, which coincides with the answers to the third question (regarding the possession of skills in a related specialty). At the same time, the share of doctors who were invited as a consultant by other specialists, on the contrary, decreased from $88.0 \%$ to $73.2 \%$. This is indirect evidence of an increase in the list of surgical interventions performed by other specialists and a decrease in the need for external consultants.

The smallest difference in the answers of doctors between 2016 and 2020 is observed in the latest questions regarding the advantages and disadvantages. There is only a slight tendency to increase the proportion of doctors, who consider the main advantage of avoiding repeated surgical interventions, and the disadvantage - the increased duration of the operation. There is no clear answer to these questions among researchers who specifically deal with this problem.

\section{Discussion}

The data obtained indicate a positive trend in the attitude of practitioners to simultaneous operations and the number of physicians with relevant skills. On the other hand, discussions on the safety of simultaneous interventions are still ongoing. Some authors report that they do not increase the duration of inpatient treatment and the frequency of early and late complications, but improve the quality of life compared to isolated hernioplasty [11, 13], according to other data, the number of complications increases significantly $[10,12]$. W. Ueland and co-authors in 2020 found that additional surgical procedures are a risk factor for increasing the duration of hospitalization [24]. A large-scale study found that after simultaneous surgery for breast cancer combined with genital pathology, patients had a longer duration of inpatient treatment, the frequency of complications, re-hospitalizations and surgeries. The authors believe that this may delay the necessary adjuvant chemotherapy [23]. Among the negative consequences of simultaneous operations, the increase in the duration of the operation is most often mentioned. Thus, hernioplasty of ventral hernias with the use of a grid during colorectal interventions increased the duration of surgery (195.8 \pm 98.7 vs. $164.3 \pm 84.4$ minutes in isolated colorectal interventions).
However, this did not affect postoperative mortality, the frequency of complications and the duration of inpatient treatment, which indicated the feasibility of such interventions [3]. In addition, the results of individual studies indicate that simultaneous operations lead to an increase in the duration of surgery and anesthesia, as well as to an increase in the frequency of adverse events and the duration of hospitalization. In particular, this was observed in simultaneous laparoscopic cholecystectomy and laparoscopic bariatric surgery [6].

It should be noted that there are many more reports of positive results of simultaneous operations. Simultaneous laparoscopic cholecystectomy with other operations, in particular, with hernioplasty, is especially often performed $[2,5,18,25]$. In addition to good results, there are enough reports of significant economic impact. Thus, a study by S. Hayakawa and co-authors conducted in 2018 found that the average cost of treatment for simultaneous laparoscopic cholecystectomy and inguinal plastic surgery was $\$ 7,673$, while the cost of separate hernioplasty and laparoscopic cholecystectomy is more than $\$ 10,000$ [9]. Other authors present data from 22 similar operations performed, which resulted in 1 case of gallbladder perforation, 1 case of ipsilateral testicular atrophy and 1 case of seroma. There were no infectious complications [18]. Simultaneous operations during laparoscopic cholecystectomy did not result in conversion in any way, did not affect the frequency of postoperative complications and length of stay in the hospital. The authors consider these operations as a good alternative to two separate interventions [5]. Simultaneous operations are often performed in patients with hiatal hernias, in whom hernioplasty is combined with bariatric surgery and antireflux intervention is recommended [7, 21]. In addition, hernioplasty is considered appropriate in urological surgeries [19, 22] and in colorectal surgery [3, 4].

Thus, the results of the work of many scientists also confirm the unresolved problem of expediency and safety of simultaneous interventions, and therefore research in this direction does not stop.

The range of simultaneous operations is very large. Further development of technologies for their implementation and methods of perioperative support, aimed at reducing the risk of adverse events after surgery, is an important area of further research.

\section{Conclusions}

Thus, the vast majority of respondents note that the implementation of simultaneous operations in everyday surgical practice is appropriate and this opinion grows with the years and experience of surgeons in laparoscopic surgery. More than half of the respondents perform such interventions in their surgical practice.

The majority of respondents believe that the main advantage of simultaneous operations is the avoidance of repeated interventions and general anesthesia. 
For the further development of simultaneous operations in combined pathology it is necessary to train "endoscopic surgeons", who must have many surgical techniques, be familiar with all possible intra- and postoperative

\section{References}

[1] Altmark, E. M. (2007). Simultaneous laparoscopic operations (literature review). Journal of Surgery, 166(4), 117-125.

[2] Arafat, S., \& Alsabek, B. (2017). Simultaneous laparoscopic cholecystectomy and transabdominal preperitoneal hernioplasty: two case reports evaluate the safety and surgical complications. Clinical Case Reports, 12(5), 2093-2096. doi: 10.1002/ccr3.1141

[3] Benlice, C., Gorgun, E., Aytac, E., Ozuner, G., \& Remzi, F. H. (2015). Mesh herniorrhaphy with simultaneous colorectal surgery: a case-matched study from the American College of Surgeons National Surgical Quality Improvement Program. Am. J. Surg., 210(4), 766-771. doi: 10.1016/j.amjsurg.2015.04.018

[4] Bizzoca, C., Delvecchio, A., Fedele, S., \& Vincenti, L. (2019). Simultaneous Colon and Liver Laparoscopic Resection for Colorectal Cancer with Synchronous Liver Metastases: A Single Center Experience. J. Laparoendosc. Adv. Surg. Tech A., 29(7), 934-942. doi: 10.1089/lap.2018.0795

[5] Caglia, P., Tracia, A., Amodeo, L., Tracia, L., Amodeo, C., \& Veroux, M. (2015). Laparoscopic cholecystectomy and concomitant diseases effectiveness of the single step treatment. Ann. Ital. Chir., 86, 524-527.

[6] Dorman, R. B., Zhong, W., Abraham, A. A., Ikramuddin, S., AlRefaie, W. B., Leslie, D. B., \& Habermann, E. B. (2013). Does concomitant cholecystectomy at time of Roux-en-Y gastric bypass impact adverse operative outcomes? Obes. Surg. 23(11), 1718-1726. doi: 10.1007/s11695-013-1001-4

[7] Garg, H., Vigneshwaran, B., Aggarwal, S., \& Ahuja, V. (2017). Impact of concomitant laparoscopic sleeve gastrectomy and hiatal hernia repair on gastro-oesophageal reflux disease in morbidly obese patients. J. Minim. Access. Surg., 13(2), 103108. doi: $10.4103 / 0972-9941.201730$

[8] Gerbali, O. Ju. (2014). Simultaneous operations in patients with chronic calculous cholecystitis. Endoscopic surgery, 6, 2628.

[9] Hayakawa, S., Hayakawa, T., Inukai, K., Miyai, H., Yamamoto, M., Kitagami, H. ... Tanaka, M. (2018). Simultaneous transabdominal preperitoneal hernia repair and laparoscopic cholecystectomy: A report of 17 cases. Asian J. Endosc. Surg., 8. doi: 10.1111/ases.12667

[10] Koolen, P. G., Ibrahim, A. M., Kim, K., Sinno, H. H., Lee, B. T., Schneider, B. E. ... Lin, S. J. (2014). Patient selection optimization following combined abdominal procedures: analysis of 4925 patients undergoing panniculectomy/ abdominoplasty with or without concurrent hernia repair. Plast. Reconstr. Surg., 134(4), 539-550. doi: 10.1097/ PRS.0000000000000519

[11] Le Gall, H., Reibel, N., De Runz, A., Epstein, J., \& Brix, M. (2017). Abdominoplasty and simultaneous laparoscopic ventral hernia repair. Clinical study about 45 patients. Ann. Chir. Plast. Esthet., 62(2), 115-121. doi: 10.1016/j.anplas.2016.06.005

[12] Michot, A., Alet, J. M., Pelissier, P., Grolleau-Raoux, J. L., Bodin, F., \& Chaput, B. (2016). Morbidity in combined-procedure associating abdominoplasty and breast surgery: A systematic review. Ann. Chir. Plast. Esthet., 61(1), e9-e19. doi: 10.1016/ j.anplas.2015.07.009

[13] Moreno-Egea, A., Campillo-Soto, A., \& Morales-Cuenca, G. complications and be able to control them at each stage of intervention, have experience in open surgical interventions to convert in a timely and professional manner with certain complications.

(2016). Does abdominoplasty add morbidity to incisional hernia repair? A randomized controlled trial. Surg. Innov., 23(5), 474480. doi: $10.1177 / 1553350616646480$

[14] Murodov, A. I., \& Kadyrov, Z. A. (2017). Simultaneous video endoscopic surgery for combined diseases of the abdominal cavity and retroperitoneal space. Medical Bulletin of Bashkortostan, 12(3 (69): 129-134

[15] Orr, N. T., Davenport, D. L., \& Roth, J. S. (2013). Outcomes of simultaneous laparoscopic cholecystectomy and ventral hernia repair compared to that of laparoscopic cholecystectomy alone. Surg. Endosc., 27(1), 67-73. doi: 10.1007/s00464-0122408-z.

[16] Petri, A., \& Savin, K. (2015). Visual medical statistics. M.: GEOTAR-Media.

[17] Processing of sociological questionnaires. Electronic resource: Access mode https://oca.com.ua/index.php?t=101

[18] Quezada, N., Maturana, G., Pimentel, E., Crovari, F., Munoz, R., Jarufe, N., \& Pimentel, F. (2019). Simultaneous TAPP inguinal repair and laparoscopic cholecystectomy: results of a case series. Hernia, 23(1), 119-123. doi: 10.1007/s10029-018-1824-y

[19] Schulster, M. L., Cohn, M. R., Najari, B. B., \& Goldstein, M. (2017). Microsurgically assisted inguinal hernia repair and simultaneous male fertility procedures: rationale, technique and outcomes. J. Urol., 198(5), 1168-1174. doi: 10.1016/ j.juro.2017.06.072

[20] Semjonov, V. V., \& Kurygin, A. A. (2014). Simultaneous operations on the abdominal organs: controversial and obvious aspects of the problem. Surgery Herald, 173(6), 96-99.

[21] Soricelli, E., Casella, G., Rizzello, M., Cali, B., Alessandri, G., \& Basso, N. (2010). Initial experience with laparoscopic crural closure in the management of hiatal hernia in obese patients undergoing sleeve gastrectomy. Obes. Surg., 20, 1149-1153. doi: 10.1007/s11695-009-0056-8

[22] Tanaka, Y., Okamura, T., Chaya, R., Nagai, T., Kobayashi, D., Kobayashi, T. ... Yasui, T. (2018). Outcomes and Complications of Simultaneous Laparoscopic Cystectomy and Laparoscopic Nephroureterectomy with Umbilical Reduced Port Surgery. Asian. Pac. J. Cancer Prev., 19(12), 3495-3500. doi: 10.31557/ APJCP.2018.19.12.3495

[23] Tevis, S. E., Steiman, J. G., Neuman, H. B., Greenberg, C. C., \& Wilke, L. G. (2019). Postoperative complications in combined gynecologic, plastic, and breast surgery: An analysis from National Surgical Quality Improvement Program. Breast J., 25(6), 1111-1116. doi: 10.1111/tbj.13429

[24] Ueland, W., Walsh-Blackmore, S., Nisiewicz, M., Davenport, D. L., Plymale, M. A., Plymale, M. \& Roth J. S. (2020). The contribution of specific enhanced recovery after surgery (ERAS) protocol elements to reduced length of hospital stay after ventral hernia repair. Surg. Endosc., 34(10), 4638-4644. doi: 10.1007/s00464-019-07233-8

[25] Vettoretto, N., Bartoli, M., Montori, G., \& Giovanetti, M. (2012). Combined laparoscopic cholecystectomy and incisional hernia repair: a proposal for standardised technique. Annals of the Royal College of Surgeons England, 94(8), 606. doi: 10.1308/ $003588412 \times 13373405387096 i$ 
ПОЗИТИВНИЙ ТРЕНД ВІДНОШЕННЯ ХІРУРГІВ УКРАЇНИ ДО СИМУЛЬТАННИХ ОПЕРАЦІЙ: АНАЛІЗ РЕЗУЛЬТАТІВ ОПИТУВАНЬ Пархоменко К.Ю., Бойко В.В., Калінкіна Н.В., Дроздова А.Г.

В останні роки спостерігається збільшення уваги до симультанних операцій, але їх частота не відповідає дійсним потребам. Мета дослідження - з'ясувати динаміку інфрормованості хірургів про симультанні операції при поєднаній абдомінальній патології. Проаналізовані результати анкетування лікарів-хірургів хірургічних стаціонарних відділень обласних, районних та міських лікарень, а також інститутів та університетських клінік Полтавської, Сумської, Рівненської, Харківської, Луганської та Донецької областей (за виключенням непідконтрольних украӥнській владі територій). Вибірка була випадковою в межах однорідної генеральної сукупності лікарів-хірургів. Перше опитування, до якого увійшли 724 лікаря, здійснено у 2016 році. У повторному опитуванні (проведено у 2020 році) брали участь 153 лікаря. Предметом опитування був стан проведення симультанних оперативних втручань у хірургічних відділеннях та особисте відношення спеціалістів до цього виду втручань. Порівняння результатів опитування 2016 та 2020 років здійснено із застосуванням критерію $\chi^{2}$. У відповідях на питання про доцільність здійснення симультанних операцій спостерігається збільшення питомої ваги лікарів, які вважають таке втручання доцільним - з 86,3\% до 96,7\%. Наступні питання демонструють, що практикуючі хірургі частіше самі виконують симультанні втручання - їх питома вага зросла з 66,3\% до 86,3\%. При цьому кількість лікарів, що володіють навичками та знаннями суміжної спеціальності, зросла на 20\% (з 27\% до 47,1\%), однак, це все ще менше половини лікарів. Частка лікарів, що вважають доцільним оволодіти суміжною спеціальністю для можливості здійснення більщого спектру симультанних втручань, зросла з 68,0\% до 80,4\%. Питома вага лікарів, що володіють мініінвазивними методиками для виконання симультанних операцій зросла з 26,0\% до 55,6\%. Спостерігається позитивний тренд відношення практикуючих лікарів до симультанних операцій. Для подальшого розвитку симультанних операцій при поєднаній патології необхідна підготовка "ендоскопічних хірургів", які повинні володіти навичками суміжних спеціальностей.

Ключові слова: симультанні операції, абдомінальна патологія, опитування, динаміка суб'єктивного відношення. 